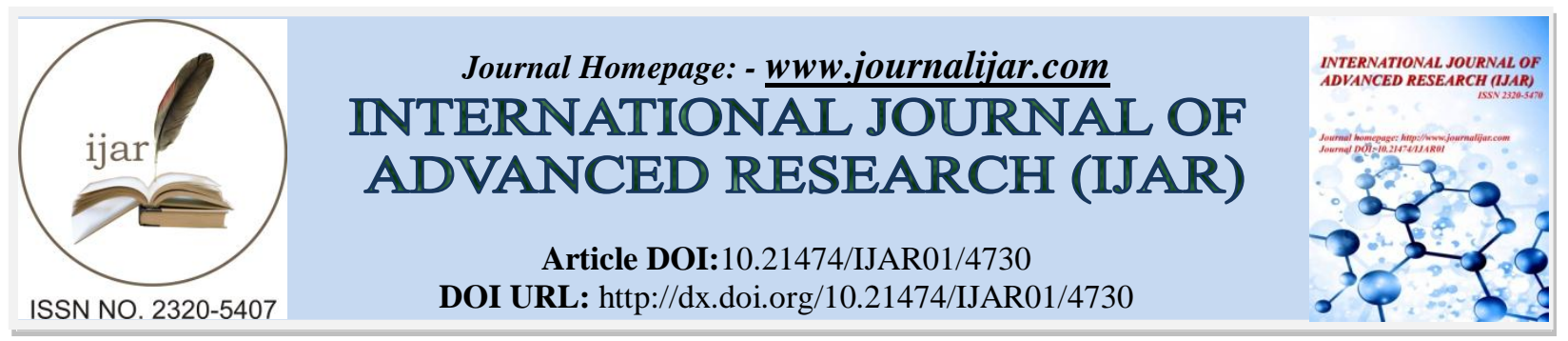

RESEARCH ARTICLE

\title{
ON-FARM INCOME DIVERSIFICATION DECISIONS AMONG RURAL FARM HOUSEHOLDS IN ENUGU STATE, NIGERIA.
}

Osuafor, Ogonna O. and Nwankwo, Temple N.

Department of Agricultural Economics and Extension, Nnamdi Azikiwe University, Awka, Anambra State, Nigeria.

\section{Manuscript Info}

\section{Manuscript History}

Received: 4 May 2017

Final Accepted: 6 June 2017

Published: July 2017

Key words:-

On-farm, income diversification, farm households

\section{Abstract}

There has been a drive on the part of consumers, producers, researchers and policy makers for a transition toward a new phase of agriculture. Diversifying income among farm households is critical to this drive. This study therefore investigated the on-farm income diversification decisions of rural farm households in Anambra State. The descriptive survey involved 235 farm households randomly selected from three agricultural zones in Enugu State, Nigeria. Three research questions were posed to guide the conduct of the study. A 23item structured questionnaire which had a reliability co-efficient of 0.78 was used to collect data. Data were analysed using mean, frequency and exploratory factor analysis. Results showed that fortytwo percent of the household heads were within the productive age range of 41-50 years. Farming was the major occupation of the respondents with majority having a household size of not more than two hectares. Average annual on-farm income was N158,000.00, $\mathrm{N} 132,000.00$ and $\mathrm{N} 215,000.00$ for crop farming, livestock farming and mixed farming respectively. The constraints in raising income from the various sources of farm income were institutional, financial and infrastructural constraints. Based on these findings, some recommendations were made that include farmers should include highly valued agricultural products in their farm activities which will boost diversification selection and therefore increase farm income. Youths should be encouraged to participate in on-farm income diversification since they are better positioned to diversify farming activities.

Copy Right, IJAR, 2017,. All rights reserved.

\section{Introduction:-}

Nigeria has been an agricultural economy since the colonial period up to the 1970s when we witnessed the oil boom. The agricultural sector contributed over $60 \%$ to the country's Gross Domestic Product (Ogwumike and Akinnibosun, 2013). It has been realized that agricultural sector in Nigeria is currently a key sector that can address the multiple challenges which has kept the country from achieving broad-based economic growth, increasing household incomes, increasing employment and reducing food/nutrition insecurity and poverty (Stakeholder's Forum, 2009). The forum stated that agriculture provides $88 \%$ of non-oil foreign exchange earnings. 
According to Enete and Achike (2008), no less than a quarter of the world population belongs to the farm households. One way or another, their livelihoods depend on agriculture. This is to say that agriculture and allied activities are the mainstay of the people living in rural areas (Pal and Biswas, 2011). Ogwumike and Akinnibosun (2013) stated that agriculture is the economic stronghold of majority of households in Nigeria, the source of livelihood for about $90 \%$ of the rural population and provides raw materials for agro-allied industries. The rural farm households are the country's major hope for sustained agricultural production as major investments in agriculture are targeted in arable lands in the rural areas.

Farm households have many challenges which include income variability (Adebayo, Akogwu\&Yisa, 2012). This is because high levels of income inequality are likely to create a hostile atmosphere for economic growth and development (Adepoju\&Oyewole, 2014). Enete and Achike (2008) asserted that unstable income of farm households could be accounted for by unfavourable weather changes, outbreak of plague, pollution in coastal waters, eruption of negative externalities, and other uncertainties which pose threats to farming activities and yields, thereby causing income to fluctuate erratically. Within this vision, diversifying income with respect to farming households has emerged to maintain ecosystem services critical to agricultural production (Bowman \&Zilberman, 2013).

Most rural households in developing countries are undergoing the process of diversifying their income sources (Zhao \& Barry, 2013). Gomes and Livan (2004) opined that rural households adjust their activities to exploit attractive new productive opportunities. Rural households in many different countries have been found to diversify their income sources allowing them to spread risk (Ellis, 1998, in Ibrahim, Rahman, Envulus\&Oyewole, 2009). The food crisis experienced in 2006 which soared in 2007 (Stakeholders Forum, 2009) seemed to have driven rural farmers to delve into diversification. Several researchers maintained that these adjustments in agricultural activities are found to have an important impact on income, income distribution and welfare across rural households (Block \& Webb, 2001; Ibrahim \&Onuk, 2009).

Diversification can be referred to as a process in which households voluntarily or involuntarily increase the number of economic activities they are involved in so as to improve household income (Zhao \& Barry, 2013). Abdulai and CroleRees (2001) maintained that income diversification is the allocation of productive resources among different income generating activities, both on-farm and off-farm. Some researchers asserted that income diversification involves adding income-generating activities including livestock, crop, non-farm and off-farm activities (Barrett, Bezuneh\&Aboud, 2000; Reardon, Berdegue, Barrett \&Stamoulis, 2006). Income diversification among rural farmers is geared towards improving their household livelihood (Dixon, Gulliver \& Gibbon, 2001). More comprehensively Minot, Epprecht, Anh and Trung (2006) stated that income diversification has been used to describe four distinct but related concepts. One definition refers to an increase in the number of sources of income or the balance among the different sources (Ijaiya, Ijaiya, Bello, Ijaiya, Ajayi, \&Adeyemi, 2010). A second definition concerns the switch from subsistence food production to commercial agriculture. This also implies an increasing mix of income activities on the farm. Thirdly, income diversification is often used to describe expansion in the importance of non-crop or non-farm income. Fourthly, income diversification can be defined as the process of switching from low-value crop production to higher-value crops, livestock and non-farm activities (Ibrahim \&Onuk, 2009). For this study, diversification is defined as the act or practice of producing and/or processing a variety of farm products so that a failure in or an environmental slump affecting one of them will not be devastating on the farm household.

Nigeria's agricultural sector has a high potential for increased growth, but this potential is not being fully realised. Agriculture still suffers from a wide range of distortions and influences that limit its contribution to food sustainability. According to Olugbire, Falusi, Adeoti, Oyekale\&Adeniran (2011), diversification is being advocated in many parts of rural Nigeria today to ensure food security. Hence, the need to investigate into the on-farm income diversification decisions among rural farm households. Perhaps, farm households that have more assets should be less risk averse and more willing to participate in market production, while farm households with fewer assets are more likely to settle for subsistence production in a desire to avoid high transaction costs in selling crops and buying food (Olale\&Nazli, 2010). The researcher's interest here is whether the decisions they take is in the best pursuit of improving the general economy and rural economy in particular. Understanding the decisions of farming households with regard to how they allocate their income among several farming activities is crucial for adjusting farming and rural policies. Babatunde and Qaim (2009) affirmed that more research is needed to understand what conditions lead to what outcomes in order to identify appropriate policy responses. Again, income diversification has received 
minute attention in agricultural economics and extension literatures in Nigeria. Hence, the gap this study seeks to fill is to highlight the key factors driving rural farm households in their decisions to diversify income among alternative production activities (on-farm diversification). This constitutes the problem of the study.

Recent changes in the agricultural sector have focused attention on the role of income diversification on farm household to boost agriculture (Mishra, Erickson, Harris, Hallahan\&Uematsu, 2010). Various explanations for income diversification behaviours can be found in economics literature to explain both incentives and disincentives for rural households to combine traditional crops with new crops and agricultural crops with animal husbandry or forestry activities (Demurger, Fournier \& Yang, 2010). A farmer is likely to hold at least more than one income portfolios on his/her farm depending on socio-economic, business and bio-physical characteristics in the environment. The decision to choose a given enterprise is a behavioural response arising from a set of alternatives and constraints facing the decision maker (Wanyama, Mose, Odendo, Okuro, Owuor\& Mohammed, 2010).

\section{Objectives of the Study:-}

The specific objectives of the study were to:

1. describe the socio-economic characteristics of rural farmers in the study area;

2. identify the various sources of on-farm income of the rural households and

3. examine the constraints in raising income from the various sources of farm income.

\section{Theoretical Framework:-}

Given that rural farm household is the unit of analysis, the theory of agricultural household model is appropriate for the study. The agricultural household model incorporates production and consumption decisions of households into a single unit (Taylor \& Adelman, 2003). The roots of the theory lie in Chayanov's 1920 findings and conclusions that the size and demographic structure of the household determined its decision-making in terms of resource allocation. Farm households choose the best combinations and quantities of commodities in the conventional way by maximising their utility function subject to prices and constraints on resources (Karttunen, 2009). There are two broad classes of this model used in most empirical studies - separable and non-separable. The household model is non-separable when the production decision is affected by consumption preferences (Taylor \& Adelman, 2003). Under this case, production and consumption decisions are linked because the decision maker is both a producer who is choosing the allocation of labour and other inputs to farm production and at the same time, is a consumer choosing the allocation of income from farm profits and labour sales to the consumption of commodities and services. The non-separable agricultural model provides the theoretical basis for the analysis of on-farm diversification decisions of rural farm households.

\section{Method:-}

The study was carried out in Enugu State. It is made up of 246,542 registered farming households (Growth Enhancement Support Scheme, 2013). The study adopted a descriptive survey design. Multi-stage random sampling technique was used to select the respondents for the study. The study was carried out in three agricultural zones (Nsukka, Enugu Ezike and Agbani) out of six zones in the study area.

Two hundred and thirty five (235) farmers formed the sample of the study. A researcher-developed questionnaire comprising of 48 items was validated by three experts and used for data collection. Its reliability was established using Cronbach's alpha method which yielded a reliability coefficient of 0.78 . The data were analyzed using mean, frequency and exploratory factor analysis.

\section{Model Specification:- \\ Exploratory Factor Analysis:-}

Exploratory factor analysis procedure using the principal factor model with varimax rotation was employed in grouping the constraint variables into major constraint factors. In factor analysis, the factor loading under each constraint (beta weight) represent a correlation of variables (constant area) to the identified constraint factor and has the same interpretation as any correlation coefficient (Chukwuone, Agwu\&Ozor, 2006). However, only variables with loading of 0.30 and above at 10 percent overlapping matrix have high loading and were used in naming the factors (Kessler, 2006). The problems enumerated by the respondents were grouped using Principal Component Analysis (PCA) or factor loading with iteration and varimax rotation. 
The model is specified As:-

$\mathrm{Y}_{1}=\mathrm{a}_{11} \mathrm{X}_{1}+\mathrm{a}_{12} \mathrm{X}_{2}+* * *+\mathrm{a}_{1 \mathrm{n}} \mathrm{X}_{\mathrm{n}}$

$Y_{2}=a_{21} X_{1}+a_{22} X_{2}+* * *+a_{2 n} X_{n}$

$\mathrm{Y}_{3}=\mathrm{a}_{31} \mathrm{X}_{1}+\mathrm{a}_{32} \mathrm{X}_{2}+* * *+\mathrm{a}_{3 \mathrm{n}} \mathrm{X}_{\mathrm{n}}$

$\mathrm{Yn}=\mathrm{a}_{\mathrm{n} 1} \mathrm{X}_{1}+\mathrm{a}_{\mathrm{n} 2} \mathrm{X}_{2}+* * *+\mathrm{a}_{\mathrm{nn}} \mathrm{X}_{\mathrm{n}}$

Where

$\mathrm{Y}_{1}, \mathrm{Y}_{2}, \mathrm{Y}_{3}, \ldots, \mathrm{Y}_{\mathrm{n}}=$ observed variables/constraints to raising income from various farming activities

$\mathrm{a}_{1}-\mathrm{a}_{\mathrm{n}}=$ constraint loading or correlation coefficients

$\mathrm{X}_{1}, \mathrm{X}_{2}, \ldots, \mathrm{X}_{\mathrm{n}}=$ unobserved underlying problems constraining farmers from raising income from various farming activities (Enete\&Amusa, 2010).

\section{Results and Discussion:-}

The results of field survey were presented according to the objectives of the study as follows:

Objective 1 Socio-economic Characteristics of the Respondents:-

The socio-economic characteristics of the respondents such as their: sex, age, marital status, educational level, household size, major occupation and farm size were considered. Results obtained are presented in Table 1.

Table 1:-Percentage Distribution of Socio-economic Characteristics of the Rural Farmers.

\begin{tabular}{|c|c|c|c|}
\hline \multicolumn{2}{|c|}{ Socio-economic Characteristics } & Frequency & Percentage $(\%)$ \\
\hline \multirow[t]{2}{*}{ Gender } & Male & 89 & 37.87 \\
\hline & Female & 146 & 62.13 \\
\hline \multirow[t]{5}{*}{ Age (Years) } & $21-30$ & 24 & 10.21 \\
\hline & $31-40$ & 62 & 26.38 \\
\hline & $41-50$ & 97 & 41.28 \\
\hline & $51-60$ & 33 & 14.04 \\
\hline & $61-70$ & 19 & 8.09 \\
\hline \multirow[t]{4}{*}{ Marital status } & Single & 61 & 25.96 \\
\hline & Married & 145 & 61.70 \\
\hline & Separated & 09 & 3.83 \\
\hline & Widowed & 20 & 8.51 \\
\hline \multirow[t]{4}{*}{ Educational level } & No formal education & 19 & 08.08 \\
\hline & $1-6$ & 48 & 20.43 \\
\hline & $7-12$ & 62 & 26.38 \\
\hline & $13-18$ & 106 & 45.11 \\
\hline \multirow[t]{3}{*}{ Household size (persons) } & $1-5$ & 139 & 59.15 \\
\hline & $6-10$ & 78 & 33.19 \\
\hline & $11-15$ & 18 & 7.66 \\
\hline \multirow[t]{4}{*}{ Major Occupation } & Farming & 103 & 43.83 \\
\hline & Civil servant & 30 & 12.77 \\
\hline & Trading & 74 & 31.49 \\
\hline & Artisan & 28 & 11.91 \\
\hline \multirow[t]{4}{*}{ Farm Size (Hectares) } & $0.5-2$ & 125 & 53.19 \\
\hline & $2.1-4$ & 72 & 30.64 \\
\hline & $4.1-6$ & 24 & 10.21 \\
\hline & $6.1-8$ & 14 & 5.96 \\
\hline
\end{tabular}

Table 1 shows that the male household heads constitute about 38 percent while females constitute about $62 \%$. This implies that the farming businesses in the study area are mostly headed by the females. This result is similar to the findings of Wanyama et al. (2010) who reported that men are much more likely to engage in any occupation other than farm labour unlike the women. Majority of the farmers belong to the active labour force (41-50 years) and are expected to take appropriate decision towards diversification of farm activities. This is in line with the findings of Babatunde and Qaim (2009) who reported that a household with more economically active adults will more likely have more income sources. There is low level of illiteracy amongst farmers which will enable them to be more receptive to opportunities in diversifying their income sources. Most of the farmers in the study area are predominantly farmers with a farm size of 0.5 to 2 hectares. 
Objective 2: Various sources of on-farm income of the rural households

The frequency distribution of respondents according to sources of on-farm income is shown in Table 2

Table 2:- Frequency Distribution of Respondents According to Sources of On-farm Income

\begin{tabular}{|c|c|c|}
\hline Sources of On-farm Income & Frequency & Percentage \\
\hline Crop Farming & 63 & 26.81 \\
\hline Livestock Farming & 54 & 22.98 \\
\hline Mixed Farming & 118 & 50.21 \\
\hline Total & 235 & 100 \\
\hline
\end{tabular}

Table 2 shows three main sources of on-farm income by the rural farm households in the study area. The result shows that majority $(50.21 \%)$ of the respondents engage in mixed farming which implies that the farmers in the study area are likely to hold more than one income portfolio on his/her farm. The study also found that some respondents employed diversification that concentrated on the production of a few key staples (such as maize, cassava and oil palm) together with complementary fruit and vegetable crops and poultry production. This is similar to Bowman and Zilberman's (2013) findings who noted that most regions in Greece and France employed diversified farming systems that concentrated on the production of rice, wheat or barley together with complementary vegetable crops and livestock production for its flexibility and for fertilizer production.

The average annual on-farm household income by sources is shown in table 3 .

Table 3:-Average Annual On-farm Household Income by Sources

\begin{tabular}{|c|c|c|c|}
\hline Income Sources & Average Annual On-farm Income (N) & Frequency & Percentage \\
\hline Crop Farming & $158,000.00$ & 63 & 26.81 \\
\hline Livestock Farming & $132,000.00$ & 54 & 22.98 \\
\hline Mixed Farming & $215,000.00$ & 118 & 50.21 \\
\hline Total & $505,000.00$ & 235 & 100 \\
\hline
\end{tabular}

In table 3, income sources of the household heads per year are categorized in three sources. Most of the farmers have an average annual on-farm income of $\mathrm{N} 215,000.00$ from mixed farming. This result is comparable to the findings of Ibrahim, et al. (2009) who noted that carrying out two activities on the same farm might reduce cost of increased output, if they are linked in the same way, because production of one good reduces the unit cost of producing another good. This is an indication that farmers in the area have significantly benefitted from diverse onfarm income generating opportunities.

Objective 3: Constraints in raising income from the various sources of farm income.

The result of exploratory factor analysis is presented in table 4

Table 4:-Varimax rotated factor matrix on the constraints faced by farmers in raising income from the various sources.

\begin{tabular}{|c|c|c|c|c|}
\hline Variable Code & Variable Names & Factor I & Factor II & Factor III \\
\hline $\mathrm{Co}_{1}$ & High cost of transportation & -0.025 & 0.062 & $\mathbf{0 . 6 0 7}$ \\
\hline $\mathrm{Co}_{2}$ & Lack of capital to set up a farm business & 0.066 & $\mathbf{0 . 3 1 1}$ & 0.090 \\
\hline $\mathrm{Co}_{3}$ & Limited access to land & 0.138 & -0.003 & 0.059 \\
\hline $\mathrm{Co}_{4}$ & Bad road network & 0.097 & -0.051 & $\mathbf{0 . 3 6 0}$ \\
\hline $\mathrm{Co}_{5}$ & Lack of technical know-how & 0.068 & 0.119 & -0.098 \\
\hline $\mathrm{Co}_{6}$ & Government policy & $\mathbf{0 . 3 8 9}$ & 0.185 & -0.123 \\
\hline $\mathrm{Co}_{7}$ & Lack of collateral to secure loan & $\mathbf{0 . 4 0 3}$ & 0.120 & 0.055 \\
\hline $\mathrm{Co}_{8}$ & High cost of labour & -0.123 & $\mathbf{0 . 6 6 9}$ & 0.169 \\
\hline $\mathrm{Co}_{9}$ & Variability of weather & -0.178 & 0.256 & 0.087 \\
\hline $\mathrm{Co}_{10}$ & Distance to farm & -0.039 & 0.100 & 0.076 \\
\hline $\mathrm{Co}_{11}$ & Price fluctuation & 0.157 & 0.065 & 0.025 \\
\hline $\mathrm{Co}_{12}$ & Limited supply of fertilizer & 0.071 & 0.260 & -0.350 \\
\hline $\mathrm{Co}_{13}$ & Distance to market & 0.179 & -0.080 & 0.012 \\
\hline $\mathrm{Co}_{14}$ & Lack of extension services & $\mathbf{0 . 3 3 8}$ & -0.015 & -0.055 \\
\hline $\mathrm{Co}_{15}$ & Low returns from farming & 0.131 & $\mathbf{0 . 9 3 2}$ & 0.000 \\
\hline $\mathrm{Co}_{16}$ & Lack of modern technologies & $\mathbf{0 . 7 0 5}$ & -0.015 & 0.009 \\
\hline
\end{tabular}


The result in table 4 shows the three major constraints named according to variables that loaded high in each factor matrix. The result of exploratory factor analysis identified the constraints as: factor I (institutional constraints), factor II (financial constraints) and factor III (infrastructural constraints) as the major problems faced by rural farm households in raising income in the study area.

Factor I is named institutional constraints because of the variable that loaded high under it which include government policy (0.389), lack of collateral to secure loan (0.403), lack of extension services (0.338) and lack of modern technologies (0.705). Factor II is named financial constraints because the variables that loaded high under it are lack of capital to set up a new farm, high cost of labour and low returns from farming. This is in line with the findings of Bowman and Zilberman (2013) who noted that financial and credit constraints are one of the constraints that play into farmers' decisions. Factor III was named infrastructural constraints because of the variables that loaded high under it which are high cost of transportation (0.607) and bad road network (0.360). This is similar to the findings of Wanyama et al. (2010) who stated that poor infrastructure will continue to be a disincentive to farmers diversifying in other farming activities.

\section{Conclusion:-}

Income diversification into on-farm activities is an important strategy in the study area. Given the increase of agricultural importance in Enugu state Nigeria, on-farm income diversification needs to be promoted particularly for the rural populace. The constraints identified in this study will be reduced to the barest minimum if the agricultural sector improves in economic performance.

\section{References:-}

1. Ogwumike, F.O. \&Akinnibosun, M.K. (2013). Determinants of poverty among farming households in Nigeria. Mediterranean Journal of Social Sciences, 4(2), 365-373. Retrieved 13/04/13 from http://dx.doi.org/10.5901/mjss.2013.4vn2p365.

2. Stakeholder Forum (2009). Sustainable agricultural development strategy and food crises response programme. A report. Feb 24-25.

3. Enete, A.A. \&Achike, A.I. (2008). Cash income diversification in rural small holder cassava producing households in Nigeria. Tropicultura,26(3), 159-163.

4. Pal, D.P. \&Biswas, M.D. (2011). Diversification of farm and non-farm sectors and structural transformation of rural economy. Retrieved from http://www.iioa.org/conferences/19th/ papers/files/586_FarmandNonFarmSectorsIOPaper2011(DP\&MDB).pdf

5. Adebayo, C.O., Akogwu, G.O. \&Yisa, E.S. (2012). Determinants of income diversification among farm households in Kaduna State: Application of tobit regression model. Publication of Nasarawa State University, Keffi, 8(2), 1-10. Retrieved 05/06/13 from http://www.patnsukjournal.net/Vol8 No2/pl.pdf.

6. Adepoju, A.O. \&Oyewole, O.O. (2014). Rural livelihood diversification and income inequality in Akinyele local government area Ibadan, Oyo State, Nigeria. Journal of Agricultural Sciences, 59(2), 175-186. Retrieved 02/06/14 from http://www.doiserbia.nb.rs/img/doi/ 1450-8109/2014/1450-81091402175A.pdf.

7. Bowman, M.S. \&Zilberman, D. (2013). Economic factors affecting diversified farming systems. Ecology and Society, 18(1), 33. Retrieved 20/04/13 from http://www.ecologyandsociety.org/vol18/iss1/art33/. http://dx.doi.org/10.5751/ES-05574-180133.

8. Zhao, J. \& Barry, P.J. (2013). Implications of different income diversification indexes: The case of rural China. Economics and Business Letters, 2(1), 13-20.

9. Gomes, J. \&Livdan, D. (2004). Optimal diversification: Reconciling theory and evidence. Journal of Finance, 59, 507-535. Retrieved 12/05/13 from http://.dx.doi.org/10.2139/ssrn.354400

10. Ibrahim, H.I., Rahman, S.A., Envulus, E.E. \&Oyewole, S.O. (2009). Income and crop diversification among farming households in a rural area of North Central Nigeria. Journal of Tropical Agriculture, Food, Environment and Extension, 8(2), 84-89.

11. Block, S. \& Webb, P. (2001). The dynamics of livelihood diversification in post-famine Ethiopia. Food Policy, 26(4), 333-350.

12. Ibrahim, H.I. \& Onuk, G.E. (2009). Analysis of rural non-farm diversification among farming households in Doma. PAT, 5(1), 49-54. Retrieved 05/05/13 from http://patnsukjournal.net/Vol5No1/p6.pdf.

13. Abdulai, A. \&CroleRees, A. (2001). Determinants of income diversification amongst rural households in Southern Mali. Food Policy, 26(4), 437-452. 
14. Barrett, C.B. \& Reardon, T.J. (2000). Asset, activity and income diversification among African agriculturists: Some practical issues. Project report to the USAID BASIS CRSP, March 2000. Washington DC.

15. Reardon, T., Berdegue, J., Barrett, C.B. \&Stamoulis, K. (2006). Household income diversification into rural non-farm activities. In S. Hagblade, P. Hazell\& T. Reardon (Eds.), Transforming the rural nonfarm economy. Johns Hopkins University Press. Chap 8. Retrieved 03/05/13 from http://www.dyson.cornell.edu/faculty_sites/cbb2/Papers/ IFPRIbookchapter2006Final.pdf

16. Dixon, J., Gulliver, A. \& Gibbon, D. (2001). Farming systems and poverty: Improving farmers' livelihoods in a changing world. In M. Hall (Ed.).FAO and World Bank.

17. Minot, N., Epprecht, M., Anh, T.T.T. \&Trung, L.Q. (2006). Income diversification and poverty in the northern uplands of Vietnam. Research report No. 145. Washington DC: International food policy research institute.

18. Ijaiya, M.A., Ijaiya, G.T. Bello, R.A., Ijaiya, M.A., Ajayi, M.A. \&Adeyemi, S.L. (2010). Determinants of income diversification in Ilorin Metropolis, Nigeria. International Economics \& Finance Journal, 5(1-2), 145157.

19. Olugbire, O.O., Falusi, A.I., Adeoti, A.I., Oyekale, A.S. \&Adeniran, O.A. (2011). Nonfarm income diversification and poverty reduction in Nigeria: A propensity-score matching analysis. Continental $J$. Agricultural Science, 5(3), 21-28.

20. Olale, E. \&Nazli, H. (2010). The influence of market barriers and farm income risk on non-farm income diversification. Paper presented at the Agricultural and Applied Economics association annual meeting, Denver, Colorado, July 25-27. Retrieved 10/05/13 from http://www.ageconsearch.umn.edu/bitstream/60915/2/nonfarmpaper.pdf

21. Babatunde, R.O. \&Qaim, M. (2009). Patterns of income diversification in rural Nigeria: Determinants and impacts. Quarterly Journal of International Agriculture,48(4), 305-320.

22. Mishra, A.K., Erickson, K. Harris, M., Hallahan, C. \&Uematsu, H. (2010). Determinants of farm household income diversification in the United States: Evidence from farm-level data. Paper presented at the Agricultural and Applied Economics association annual meeting, Denver, Colorado, July 25-27. Retrieved from http://www.ageconsearch.umn.edu/handle/61632 on 02/04/13

23. Démurger, S., Fournier, M. \& Yang, W. (2010). Rural households' decisions towards income diversification: Evidence from a township in northern China. Grouped'Analyseet de ThéorieEconomique (GATE). France: Ecullycedex.

24. Wanyama, M., Mose, L.O., Odendo, M., Okuro, J.O., Owuor, G. \& Mohammed, L. (2010). Determinants of income diversification strategies amongst rural households in maize based farming systems in Kenya. African Journal of Food Science, 4(12), 754-763. Retrieved from http://www.academic journals.org/ajfs/pdf/pdf2010/dec/wanyama\%20et\%20al.pdf. 04/05/13.

25. Taylor, J. \& Adelman I. (2003). Agricultural household models: Genesis, evolution and extensions. Review of Economics of the Household, 1(1), 33-58.

26. Karttunen, K. (2009). Rural income generation and diversification - A case study in Eastern Zambia. A dissertation presented to the Department of Economics and Management, Faculty of Agriculture and Forestry, University of Helsinki. Agricultural Policy, 47.

27. Growth Enhancement Support Scheme (GESS) (2013). Agricultural Development Programme. Ministry of Agriculture, Enugu State.

28. Chukwuone, N.A, Agwu, A.E. \&Ozor, N. (2006). Constraints and strategies towards effective cost-sharing of Agricultural Technology Delivery in Nigeria: Perception of farmers and Agricultural Extension personnel. Journal of International Agriculture and Extension Education, 13(1), 29-40.

29. Kessler, C.A. (2006). Decisive key-factors influencing farm households' soil and water conservation investments. Journal of Applied Geography, 26(1). 40-60.

30. Enete, A.A. \&Amusa, T.A. (2010). Determinants of women's contribution to farming decisions in cocoa based agroforestry household in Ekiti State, Nigeria. Field Actions Science (FACTS) Report,4, 1-6.

31. Tomich, T., Brodt, S., Ferris, H., Galt, R., Horwath, W., Kebreab, E., ... Yang, L. (2011). Agroecology: A review from a global-change perspective. Annual Review of Environment and Resources, 36, 193-222. Retrieved 12/05/13 from http://dx.doi.org/10.1146/annurev-environ-012110-121302. 